\title{
Begomovirus infection on Cucumber in Saudi Arabia
}

\author{
Sayed Sartaj Sohrab*, Muhammad Yasir, Sherif Ali El-Kafrawy
}

\author{
Special Infectious Agents Unit; King Fahd Medical Research Center, King Abdulaziz University, Jeddah, Saudi \\ Arabia
}

\section{*Corresponding author: ssohrab@kau.edu.sa}

\begin{abstract}
Cucurbits are an important vegetable crops and among them Cucumber (Cucumis sativus) used mainly as vegetables and salad. The cucumber crop was found to exhibit yellow mosaic symptoms grown in the natural field in Saudi Arabia. We collected naturally infected samples and detected the begomovirus infection by polymerase chain reaction and full length as well as betasatellites viral genome was cloned and sequenced. The sequences of the full length viral genome had 2784 and betasatellites had 1377 nucleotides respectively. In a multiple sequences analysis, highest homology was observed with Tomato yellow leaf curl virus previously reported from Jizan and Al-Qasim, Saudi Arabia. The betasatellites sequences were also analyzed but, interestingly the highest homology was observed with Tomato yellow leaf curl betasatellites reported from Jeddah and Oman. In a phylogenetic tree analysis, the closest cluster was formed with begomovirus isolates identified earlier from Jizan and Al-Qasim. Based on the results obtained in this study, it is concluded that a variant of Tomato yellow leaf curl virus associated with yellow mosaic disease of cucumber in Saudi Arabia. These findings provide valuable information about the natural infection and disease spread caused by begomovirus in new geographic regions on new host.
\end{abstract}

Keywords: Begomovirus, betasatellites, Cucumber, Genetic diversity, Phylogenetic relationships Tomato yellow leaf curl virus. Abbreviations: TYLCV_Tomato Yellow leaf Curl Virus.

\section{Introduction}

Cucumber (Cucumis sativus) belongs to the same botanical family as melons and squashes. Commercial production of cucumbers is usually divided into two types. "Slicing cucumbers" are produced for fresh consumption and widely cultivated crop around the world. Yellow mosaic, and leaf curl disease significantly limits the production of cucumber. Yellow mosaic disease of cucumber is caused by Tomato yellow leaf curl virus (TYLCV) belonging to the genus begomovirus of the family Geminiviridae. Begomovirus have circular single-stranded DNA (ssDNA) with either a monoor bipartite genome. Bipartite begomovirus genome have two circular ssDNA molecules $(\sim 2.7 \mathrm{~kb})$, well known as DNA-A and DNA-B while mono-partite begomovirus has only DNAA mostly associated with satellite molecule known as betasatellites (Lazarowitz 1992; Briddon et al., 2003). The family Geminiviridae has now been reported to have seven genera known as Mastrevirus, Curtovirus, Begomovirus, Topocuvirus, Eragrovirus, Turncurtovirus, Becurtovirus (Muhire et al., 2014; Brown et al., 2012; Brown et al., 2015; Varsani et al., 2014). Members of the genus begomovirus have circular single-stranded DNA (ssDNA) with either a mono- or bipartite genome. The bipartite begomovirus genome has two ssDNA molecules $(\sim 2.7 \mathrm{~kb})$, known as DNA-A and DNA-B while mono-partite begomovirus has only DNA-A with satellite molecule known as betasatellites (Briddon et al., 2004; Briddon et al., 2008). Betasatellites are small $(\sim 1.4 \mathrm{~kb})$, highly diverse with circular ssDNA. The betasatellites replication, movement and transmission between plants are mediated by their helper virus. Betasatellites had an open reading frame; beta $\mathrm{C} 1$, an adenine-rich region, and a satellite conserved region with 45-
93\% sequence identity (Sivalingam et al., 2010). Alphasatellites are capable of autonomous replication in host plant cells mediated by a nanovirus-like replicationassociated protein (Saunders and Stanley, 1999; Cui et al., 2004; Saunders et al., 2008). Whitefly vector (Bemisia tabaci) has emerged as serious pathogens for most of the dicotyledonous crops across tropical, sub-tropical regions across the world. The emergence and spread of TYLCV from the Middle East to world and it is suspected that Iran could be the center for TYLCV diversity (Duffy and Holmes 2008; Lefeuvre et al., 2010; Kenyon et al., 2014).

In this study, we report the natural occurrence of begomovirus, begomovirus detection, viral genome cloning and sequencing, sequence identity matrix, genetic diversity and phylogenetic relationship of TYLCV associated with yellow mosaic disease of cucumber crops. During the field survey, it was observed that the naturally infected cucumber plants exhibit yellow mosaic symptoms in Jeddah, Saudi Arabia. The association of begomovirus and causes significant loss to various crops like tomato, tobacco, okra and chili crops in the Nile Basin, arid and semi-arid southern part of the Arabian Peninsula, Oman and Yemen have been published in many reports and identified as Tomato leaf curl Sudan virus (ToLCSDV),Tomato yellow leaf curl virus (TYLCV), Tomato leaf curl Al-Batinah virus (ToLCABV),Tomato leaf curl Oman virus (ToLCOMV), Chili leaf curl virus (ChiLCV), Okra leaf curl Oman virus (OLCOMV), Tomato leaf curl Sudan virus-Oman isolate (ToLCSDV-Om) (Idris and Brown 2005; Ajlan et al., 2007; Khan et al., 2008; Fauquet et al., 2008; Idris et al., 2011; Idris et al., 2012; Khan et al., 2013a,b; Khan et al., 2014; Akhtar 
et al., 2014; Al-Saleh et al., 2014; Idris et al., 2014). The present study was undertaken to identify and characterize the begomovirus causing yellow mosaic disease of cucumber in Jeddah, Saudi Arabia.

\section{Results}

\section{Detection of Begomovirus and transmission by whiteflies on cucumber seedlings}

During the field survey, total 7 samples were randomly collected from the naturally infected cucumber Plants. Begomovirus infection was confirmed by using specific PCR primers and $\sim 856 \mathrm{bp}$ amplicon was visualized on $1 \%$ Agarose gel from infected cucumber leaf samples (Fig 2). The causative agent could be efficiently transmitted to young cucumber seedlings and the inoculated plants developed characteristic yellow mosaic symptoms in $70 \%$ plants by $6-$ 14 days after inoculation and the disease symptoms produced in the experimental plants were approximately related to those observed in the field.

\section{Cloning of viral genome, sequencing and Phylogenetic analysis with begomoviruses}

The rolling circle amplification products obtained by using total DNA extracted from naturally infected cucumber plants were restricted with EcoRI and Hind III restriction enzyme and only one clone was selected and obtained from an EcoRI restricted sample and one clone was experimentally confirmed and sequenced. The complete viral genome had 2784 nucleotides (nt) while betasatellites had 1377 nucleotides (nt). The full genome and betasatellites sequences have been submitted to NCBI-GenBank with accession numbers, KT033713-full length and KT180307-betasatellites and tentatively designated as TYLCV-Cucumber-Jeddah isolate.

The sequence analysis based on full revealed that the TYLCV-cucumber-Jeddah isolate shared greater identity ranged from $99.6 \%$ with TYLCV-Tomato-Jeddah isolate followed by 99.4-93.0\% identity with TYLCV-Jizan 103 and $\mathrm{Al}$-Qasim isolates and the lowest similarity $(71.6 \%)$ were observed with TYLCV-Egypt isolate (EF107520) and TYLCV isolates from Oman and Iran showed 79-82\% identity. The highest amino acid sequence identity was identified with TYLCV-Tomato-Jeddah isolates (KT033715) in all the 6 proteins (V2-98.9\%, V1-98.3\%, C3-98.1\%, C2$98.6 \%$, C1-98.2\%, and $\mathrm{C} 4-98.3 \%$ ) respectively, with respective sequences of selected begomovirus isolate (Table 1). The sequence analysis based on betasatellites using Tomato yellow leaf curl betasatellites-Cucumber-Jeddah KT180307 isolate with selected begomovirus from various locations showed the highest identity (99.1-99.0 \%) with Tomato yellow leaf curl betasatellites-Jeddah and Hadasham isolates (KT355021\& KT728732) while isolates from Oman ranged from (88.2-97.8\% identity) and Yemen isolates ranged from $45.2-45.9 \%$ identity and the lowest $(44.3 \%)$ identity was found with Okra Leaf Curl virus-Jordan isolate (KJ396939) (Table 2). Based on the complete genome sequence and the phylogenetic analysis with selected begomoviruses, TYLCV-Cucumber-Jeddah isolate formed a closed cluster with TYLCV isolates from Jizan and ALQasim and this result indicates that identified TYLCVCucumber-Jeddah isolate is a variant of either Jizan and ALQasim (Fig 3). Interestingly, many isolates from Oman grouped together and formed a closed cluster and only one TYLCV-Oman isolate (FJ956706) clustered with Iran isolate
(GU076448) while isolates from Egypt, Jordan and Iraq formed separate clusters. The other remaining isolates grouped on the basis of their geographical origin and formed separate clusters. The phylogenetic analysis result based on betasatellites sequences with selected begomovirus isolates formed a closed cluster with Tomato yellow leaf curl betasatellites from Jeddah, Hadasham, Tabuk and Hail. While isolates from Oman and Yemen formed separate clusters and isolates from Thailand, Vietnam, Jordan, Java and Mali formed completely separate clusters (Fig 4).

\section{Discussion}

Cucurbits are important vegetable crops and among them cucumber crops are mostly used as salad purposes. The cultivation and yield of cucumber are seriously affected by many viral diseases and globally, a yellow mosaic disease caused by begomovirus is a major limiting factor for cultivation of cucumber. Cucumber is an important vegetable crop in the Kingdom of Saudi Arabia for local consumption. In this study, we described the identification of virus infection; viral genome (full genome and betasatellites) cloning, sequencing, genetic variation and phylogenetic relationship of associated begomovirus and tentatively designated as TYLCV-cucumber-Jeddah. During the field survey, naturally infected plants were observed to exhibit yellow mosaic symptoms in a cucumber field. The emergences of many isolates of begomovirus during the last 20-30 years have become the most important groups of plant viruses. The cultivation and production of vegetable crop has been severely affected due to begomovirus and natural increase of more whiteflies population in the tropics and subtropics. The information about begomovirus genetic variability, virus evolution and host plant interaction will help to design and develop an effective and durable disease management strategy against viruses (Garcia et al., 2007). There are many important factors are known which enables virus adaptations and emergence in changed environments and climatic conditions and these factors are like mutation in coding and non-coding regions, recombination, reassortment, selection, genetic drift, interaction of virus host and virus vectors, mixed infection, high rate of replication, acquisition of satellite DNA molecules and extended host range of the whiteflies vector are known for genetic variability and evolution among the virus population (Seal et al., 2006). Recent studies have shown that Geminiviruses genomes are prone to DNA methylation in infected host plants (Yang et al., 2011; Zhang et al., 2011).

The sub-continental Southeast Asia could be a major center of diversity for begomoviruses and associated betasatellite molecules (Ha et al., 2008). But many reports have been published about the diversity and the emergence of begomovirus infecting Solanaceous crops in the East and South-East Asia (Lefeuvre et al., 2010, Yang et al., 2011; Kenyon et al., 2014). Since two decades, the cucurbits production has been seriously affected by yellow mosaic disease caused by many begomoviruses like Tomato Leaf curl Sudan Virus (ToLCSDV), TYLCV and Tomato yellow leaf curl virus-Oman, Okra leaf curl Oman Virus in Arabian Peninsula and Nile Basin (Ajlan et al., 2007; Khan et al., 2008; Idris et al., 2011, Khan et al., 2013a,b; Al-Saleh et al., 2014; Akhtar et al., 2014; Idris et al., 2014). In this study, the greater value of genetic diversity was observed based on full genome and betasatellites and phylogenetic relationships also showed the genetic diversity among begomovirus. The identified begomovirus was designated as TYLCVcucumber-Jeddah isolate which represents a variant of 
Table 1. Sequence identity matrix of TYLCV- Cucumber isolate (KT033713) with selected Begomovirus.

\begin{tabular}{|c|c|c|c|c|c|c|c|c|c|c|}
\hline \multirow{2}{*}{$\begin{array}{l}\text { Accession } \\
\text { Nos. }\end{array}$} & \multirow[t]{2}{*}{ Acronyms } & \multirow[t]{2}{*}{ Hosts } & \multirow[t]{2}{*}{ Locations } & \multicolumn{7}{|c|}{$\%$ Identity matrix } \\
\hline & & & & $\begin{array}{l}\text { Full } \\
\text { (nt) }\end{array}$ & $\begin{array}{l}\mathrm{V} 2 \\
\text { (aa) }\end{array}$ & $\begin{array}{l}\text { V1 } \\
\text { (aa) }\end{array}$ & $\begin{array}{l}\text { C3 } \\
\text { (aa) }\end{array}$ & $\begin{array}{l}\mathrm{C} 2 \\
\text { (aa) }\end{array}$ & $\begin{array}{l}\mathrm{C} 1 \\
\text { (aa) }\end{array}$ & $\begin{array}{c}\mathrm{C} 4 \\
\text { (aa) }\end{array}$ \\
\hline KT033715 & TYLCV & Tomato & Jeddah & 99.6 & 98.9 & 98.3 & 98.1 & 98.6 & 98.2 & 98.3 \\
\hline KC845301 & TYLCV & Tomato & Jizan & 99.4 & 99.3 & 99.5 & 99.2 & 99.1 & 99.0 & 99.3 \\
\hline KF561125 & TYLCV & Tomato & Al-Qasim & 93.0 & 92.6 & 92.2 & 92.5 & 91.9 & 91.8 & 90.9 \\
\hline KF435137 & TYLCV & Tomato & Alahsaa & 81.7 & 81.0 & 81.1 & 80.9 & 81.2 & 80.6 & 80.7 \\
\hline KF435136 & TYLCV & Pepper & Alahsaa & 81.3 & 81.4 & 81.2 & 80.5 & 81.1 & 81.6 & 80.9 \\
\hline HE819240 & TYLCV & Capsicum & Oman & 79.1 & 78.8 & 79.0 & 78.1 & 78.6 & 78.2 & 78.2 \\
\hline KF229726 & TYLCV & Tomato & Oman & 78.0 & 77.9 & 77.6 & 75.9 & 77.7 & 76.9 & 76.6 \\
\hline KF229725 & TYLCV & Tomato & Oman & 79.5 & 78.5 & 78.0 & 78.9 & 78.1 & 78.7 & 77.0 \\
\hline KF229724 & TYLCV & Tomato & Oman & 79.5 & 78.4 & 78.0 & 78.8 & 78.1 & 78.7 & 76.0 \\
\hline KF229723 & TYLCV & Tomato & Oman & 79.5 & 78.5 & 78.0 & 78.9 & 78.1 & 78.7 & 77.0 \\
\hline KF229722 & TYLCV & Tomato & Oman & 79.2 & 78.2 & 79.0 & 78.7 & 76.6 & 77.8 & 78.6 \\
\hline KF229721 & TYLCV & Tomato & Oman & 79.3 & 78.5 & 78.8 & 78.6 & 78.8 & 78.7 & 77.1 \\
\hline HE819245 & TYLCV & Tomato & Oman & 79.2 & 78.2 & 79.0 & 78.7 & 76.6 & 77.8 & 78.5 \\
\hline HE819243 & TYLCV & Tomato & Oman & 79.8 & 78.2 & 78.0 & 78.7 & 78.1 & 77.2 & 77.7 \\
\hline HE819242 & TYLCV & Tomato & Oman & 79.2 & 78.6 & 79.1 & 78.7 & 76.6 & 77.8 & 78.6 \\
\hline HE819241 & TYLCV & Tomato & Oman & 78.1 & 77.9 & 77.6 & 75.9 & 77.7 & 76.9 & 76.5 \\
\hline JN604488 & TYLCV & Tomato & Oman & 78.2 & 78.0 & 77.8 & 77.3 & 77.1 & 77.6 & 76.0 \\
\hline JN604487 & TYLCV & Tomato & Oman & 78.2 & 78.0 & 77.8 & 77.3 & 77.1 & 77.6 & 76.0 \\
\hline JN604486 & TYLCV & Tomato & Oman & 79.7 & 79.5 & 79.0 & 78.9 & 78.1 & 78.7 & 78.0 \\
\hline JN604485 & TYLCV & Tomato & Oman & 79.5 & 78.2 & 79.0 & 78.7 & 76.6 & 77.8 & 78.5 \\
\hline JN604484 & TYLCV & Tomato & Oman & 79.2 & 78.9 & 79.9 & 78.8 & 76.9 & 77.8 & 78.6 \\
\hline DQ644565 & TYLCV & Tomato & Oman & 82.2 & 82.0 & 81.8 & 81.2 & 81.5 & 80.9 & 80.0 \\
\hline FJ956706 & TYLCV & Tomato & Oman & 79.2 & 78.9 & 79.9 & 78.8 & 76.9 & 77.8 & 78.6 \\
\hline FJ956705 & TYLCV & Tomato & Oman & 79.1 & 78.0 & 78.8 & 78.2 & 79.0 & 78.8 & 79.0 \\
\hline FJ956704 & TYLCV & Tomato & Oman & 79.2 & 78.2 & 79.0 & 78.7 & 76.6 & 77.8 & 78.5 \\
\hline FJ956703 & TYLCV & Tomato & Oman & 79.2 & 78.2 & 79.1 & 78.6 & 78.6 & 79.0 & 78.5 \\
\hline FJ956702 & TYLCV & Tomato & Oman & 78.8 & 78.2 & 77.8 & 78.7 & 78.1 & 76.2 & 77.6 \\
\hline FJ956701 & TYLCV & Tomato & Oman & 79.2 & 78.1 & 78.9 & 78.4 & 77.6 & 77.8 & 77.6 \\
\hline KC106648 & TYLCV & Tomato & Iran & 79.2 & 78.2 & 79.0 & 78.7 & 76.6 & 77.8 & 78.6 \\
\hline AJ132711 & TYLCV & Tomato & Iran & 79.6 & 78.0 & 78.5 & 78.9 & 78.6 & 78.8 & 78.1 \\
\hline EU085423 & TYLCV & Tomato & Iran & 81.1 & 79.9 & 80.8 & 80.7 & 81.0 & 80.4 & 80.7 \\
\hline GU076448 & TYLCV & Tomato & Iran & 82.2 & 81.0 & 81.1 & 80.9 & 81.2 & 80.6 & 80.7 \\
\hline AY594174 & TYLCV & Tomato & Egypt & 79.3 & 78.5 & 78.3 & 78.6 & 78.9 & 78.8 & 76.1 \\
\hline EF107520 & TYLCV & Tomato & Egypt & 71.6 & 71.5 & 70.8 & 70.6 & 70.8 & 70.7 & 70.1 \\
\hline EF054894 & TYLCV & Tomato & Jordan & 82.7 & 82.5 & 81.8 & 81.9 & 81.4 & 81.9 & 80.0 \\
\hline GQ861426 & TYLCV & Tomato & Jordan & 72.1 & 72.0 & 70.9 & 69.9 & 68.0 & 68.7 & 70.1 \\
\hline JX131286 & TYLCV & S. arvensis & Jordan & 78.8 & 78.2 & 77.8 & 78.7 & 78.1 & 76.2 & 77.6 \\
\hline JQ354991 & TYLCV & Tomato & Iraq & 78.7 & 78.3 & 77.6 & 78.1 & 78.0 & 77.2 & 77.9 \\
\hline AY044138 & TYLCV & Tomato & Sudan & 81.9 & 80.9 & 80.8 & 81.2 & 81.0 & 80.4 & 81.7 \\
\hline
\end{tabular}

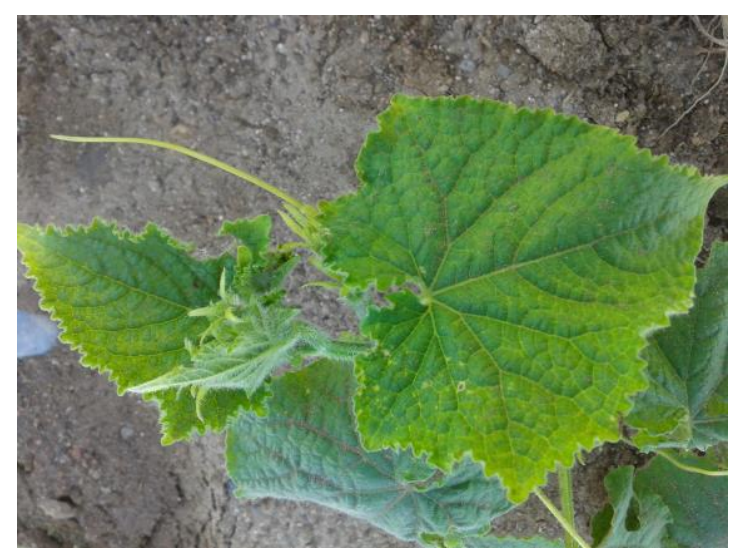

Fig 1. Naturally Infected cucumber plant exhibiting yellow mosaic symptoms. 
Table 2. \% Identity matrix of Cucumber (KT180307) Begomovirus with selected isolates.

\begin{tabular}{|c|c|c|c|c|}
\hline Accession Nos & Acronyms & Hosts & Locations & \%Identity \\
\hline KT355021 & TYLCB & Tom & Jeddah & 99.1 \\
\hline KT728732 & TYLCB & Tom & Hadasham & 99.0 \\
\hline KT728734 & TYLCB & Tom & Hail & 98.5 \\
\hline KT728740 & TYLCB & Tom & Tabuk & 98.2 \\
\hline JF919717 & ToLCYEB & Tob & Yemen & 45.2 \\
\hline JF919718 & ToLCYEB & Tob & Yemen & 45.6 \\
\hline JF919719 & ToLCYEB & Tob & Yemen & 45.7 \\
\hline JF919720 & ToLCYEB & Tob & Yemen & 45.9 \\
\hline JF919721 & ToLCYEB & Tom & Yemen & 45.8 \\
\hline JF919722 & ToLCYEB & Tom & Yemen & 45.5 \\
\hline NC_010126 & TYLCß-Om & Tom & Oman & 97.8 \\
\hline DQ644566 & TYLCß-Om & Tom & Oman & 97.4 \\
\hline HG969297 & TYLCß- Om & Pap & Oman & 90.2 \\
\hline HG969296 & TYLCß- Om & Pap & Oman & 88.2 \\
\hline HE800552 & TYLCß- Om & Tob & Oman & 93.1 \\
\hline HE800551 & TYLCB- Om & Tob & Oman & 93.5 \\
\hline HE800550 & TYLCB- Om & Tob & Oman & 91.4 \\
\hline HE800549 & TYLCB- Om & Tob & Oman & 92.0 \\
\hline HE800548 & TYLCB- Om & Tob & Oman & 92.7 \\
\hline HE800547 & TYLCß- Om & Tob & Oman & 93.7 \\
\hline HE800546 & TYLCß- Om & Tob & Oman & 94.2 \\
\hline HE800545 & TYLCß- Om & Tob & Oman & 95.1 \\
\hline HE800544 & TYLCB- Om & Tob & Oman & 92.1 \\
\hline HE800543 & TYLCB- Om & Pap & Oman & 90.5 \\
\hline HE800542 & TYLCß- Om & Pap & Oman & 93.2 \\
\hline HE800541 & TYLCB- Om & Pap & Oman & 93.6 \\
\hline HE800540 & TYLCB- Om & Pap & Oman & 92.9 \\
\hline KJ396939 & OkLCV & Okra & Jordan & 44.3 \\
\hline NC_004903 & TYLCTHVß & Tom & Thailand & 58.4 \\
\hline DQ641714 & TYLCVVß & Tom & Vietnam & 61.0 \\
\hline NC_007485 & TYLCMVB & Tom & Mali & 46.8 \\
\hline KC677734 & ToLCJaB & Tom & Java & 55.3 \\
\hline
\end{tabular}

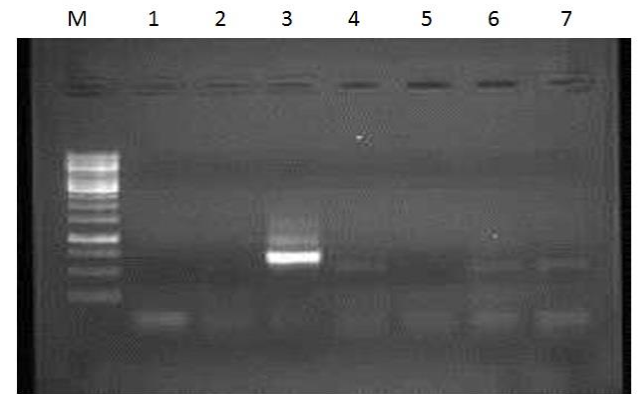

Fig 2. PCR detection of begomovirus. M: 1kb Ladder, 1: Healthy, 2-7-Field collected cucumber leaf samples.

circulating begomovirus that have spread throughout the western region and the Arabian Peninsula. The identified begomovirus isolate causing yellow mosaic disease of cucumber in Jeddah, Saudi Arabia has moved either from Yemen or from Oman. The genetic variability of begomovirus infecting cucumber in Jeddah, Saudi Arabia also could be the result of many factors like, climatic changes, change in the cropping systems, expanded crop production system, increased whiteflies population with a high disease incidence rate and virus spread to new hosts and the introduction of other begomovirus species by humans through infected plant materials. In order to better understand the current situation and genetic variability among the circulating begomoviruses and to develop an effective, sustainable management strategy for the yellow mosaic diseases, there is an urgent need not only to prepare a fine distribution map of begomovirus genotypes and types of whiteflies types across the region but also the resistance pattern and reactions of cucumber lines carrying different combinations of resistance genes against different begomovirus genotypes causing mosaic disease of cucumber in Jeddah, Saudi Arabia.

\section{Materials and Methods}

Sample collection, virus detection and whiteflies transmission

Naturally infected leaf samples from symptomatic cucumber plants displaying characteristic yellow mosaic symptoms (Fig 1) were collected during field survey in April 2014 from farmers field Jeddah, Saudi Arabia. Total genomic DNA was 


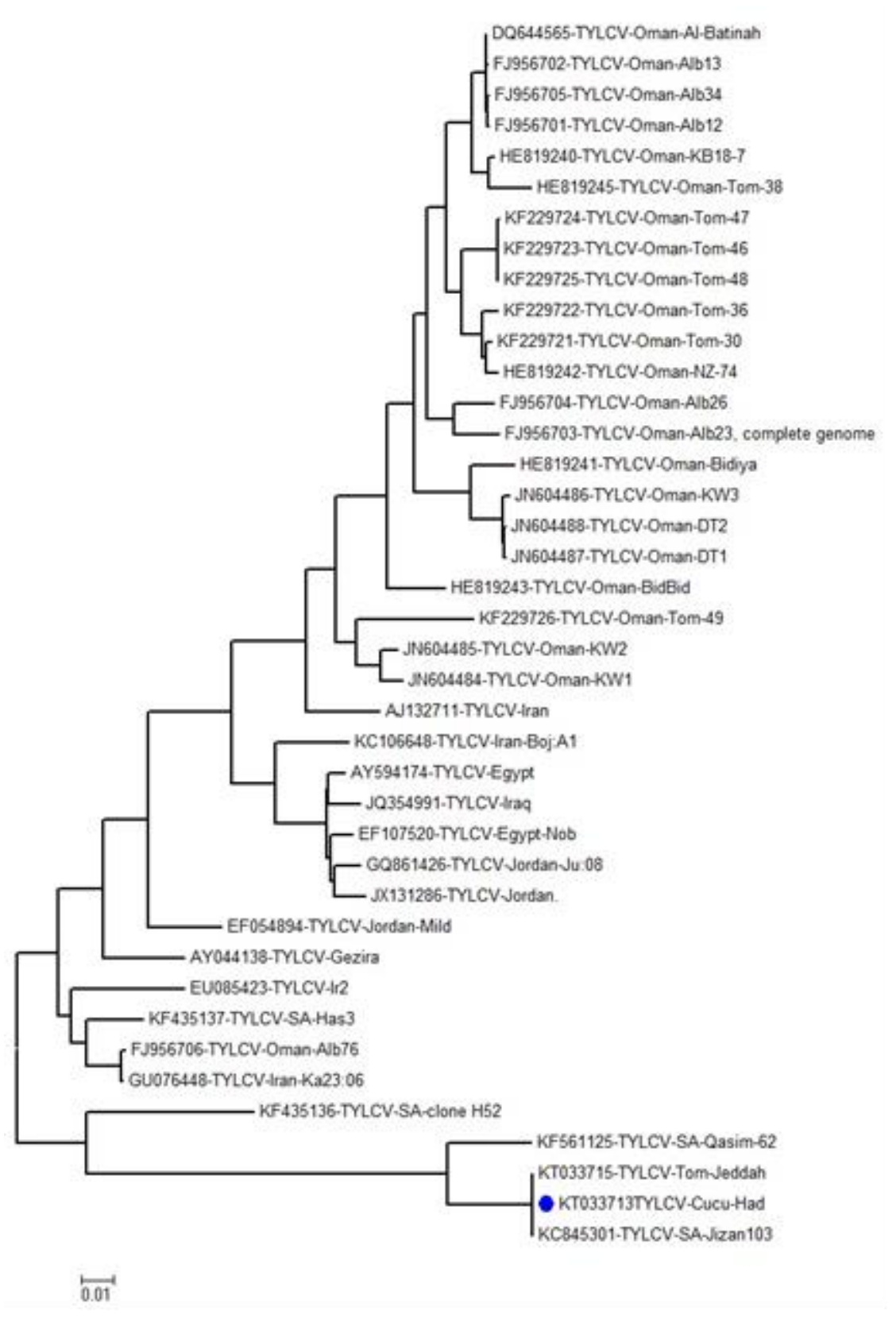

Fig 3. Phylogenetic relationships of begomovirus genome under study with selected strains (selected based on full genome BLASTn analysis) determined by NJ method within MEGA v6.1 with 1000 bootstrap replicates.

isolated from $100 \mathrm{mg}$ leaf tissue using a DNAeasy plant mini kit (Qiagen Inc.) and begomovirus infection was also confirmed by PCR using specific primers TYC1F (5'GGGCCTAGAGACCTGGCCCAC-3') and TYC1R (5'CCGGTAATATTATACGGATGGC-3') (Hosseinzadeh et al., 2014). The presence of betasatellites were also confirmed by amplifying the full-length betasatellites genome by using specific primers; beta01/beta02 (Briddon et al., 2002). Fresh culture of non-viruliferous whiteflies were raised from the whitefly eggs and maintained in a healthy Clatoria plant in insect-proof cages. Total twenty four hours of acquisition access period (AAP) were given to acquire the virus from infected leaf samples by healthy whiteflies followed by 24 hours inoculation access period (IAP) to transmit the causative agent on healthy cucumber seedlings using 15 whiteflies/cucumber plant and inoculated seedlings were further maintained and monitored for symptom development under insect-proof cages up to five-six weeks.

\section{Viral genome cloning and sequencing}

Total genomic DNA was isolated and full-length begomovirus genome was amplified by rolling circle amplification (RCA) technique using TempliPhi 100 Amplification Kit (GE Healthcare, Life Sciences, Piscataway, NJ, USA) following the manufacturer's instructions. The amplified products were digested with EcoRI and Hind III and full-length begomovirus ( 2.7 kb) fragment was cloned into the plasmid vector pUC-19 and pGEMT-easy vector was used to clone betasatellites genome. One clone of a full genome $(\sim 2.7 \mathrm{~kb})$ and betasatellites $(\sim 1.4 \mathrm{~kb})$ from cucumber plant sample were obtained and 


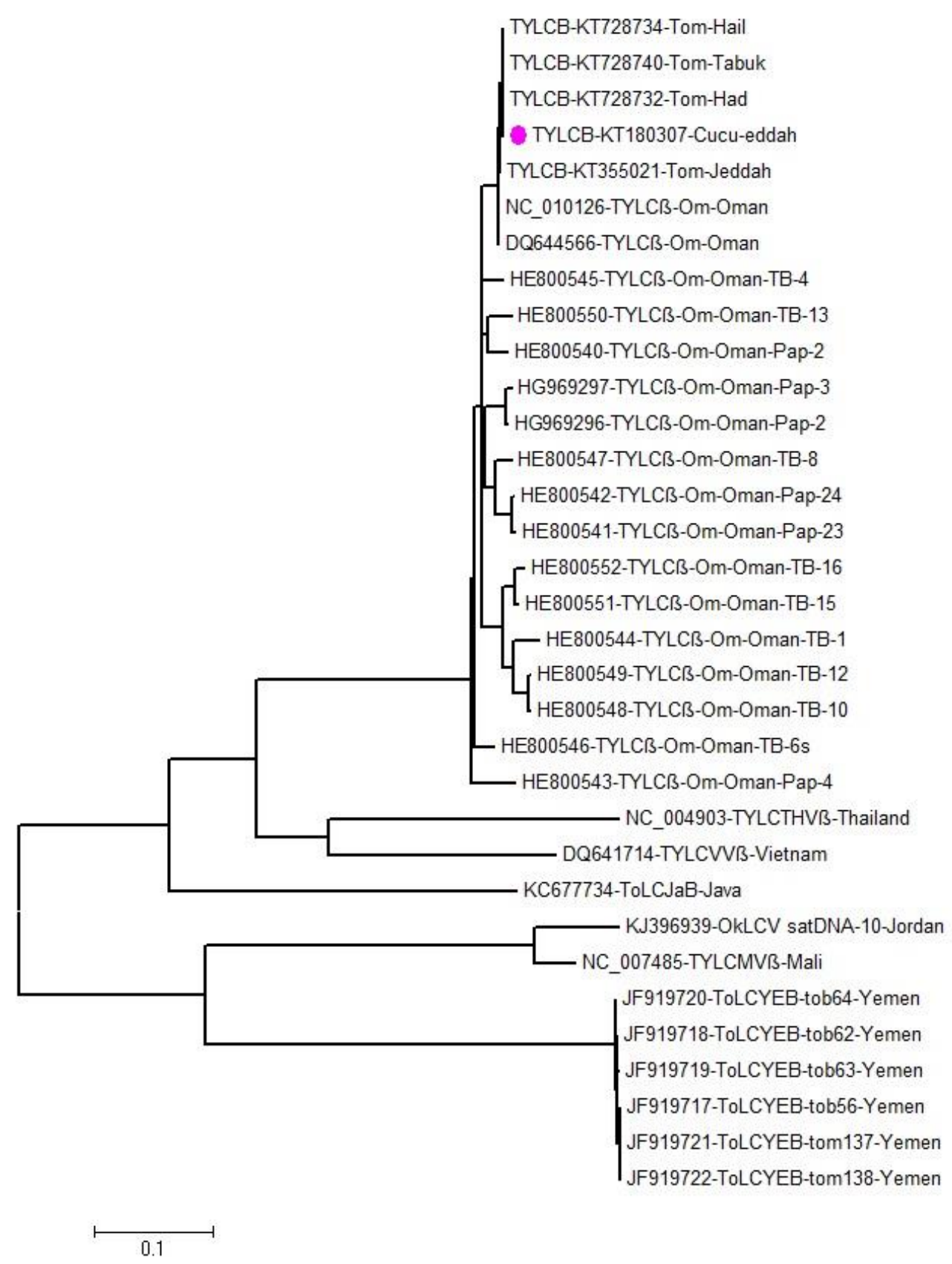

Fig 4. Phylogenetic relationships of betasatellites under study with selected strains (selected based on betasatellites BLASTn analysis) determined by NJ method within MEGA v6.1 with 1000 bootstrap replicates.

sequenced into bidirectional way. The DNA sequence was assembled and determined for full length begomoviral genomic clones by primer walking methods and analyzed by using NCBI-BLAST.

\section{Sequence and phylogenetic analysis}

The full length sequences were assembled and initially BLAST for sequence homology and percentage similarity was determined by using the software programme, BioEdit (version 5.0.9) and multiple sequence alignments were performed by using CLUSTALW program (http://www.ebi.ac.uk/clustalw) using nucleotides (nt) sequences of selected begomovirus. The phylogenetic tree was constructed by using MEGA 6 program from the aligned nucleotide sequences with neighbor-joining method (Tamura et al., 2013).

\section{Conclusion}

The results obtained in this study from full length viral genome and associated betasatellites sequences; phylogenetic analysis concludes that the identified virus causing yellow mosaic disease of cucumber in Jeddah is a variant of Tomato yellow leaf curl virus reported from the Arabian Peninsula and Nile Basin circulating in the Kingdom of Saudi Arabia.

\section{Competing Interests:}

The authors have declared that no conflict of interest exists. 


\section{Acknowledgments}

Author would like to thank General directorate of research grants (GDRG), King Abdulaziz City for Science and Technology (KACST-Riyadh) for providing large grant, bearing number: AT-66-34 and the research facility provided by Special Infectious Agents Unit, King Fahd Medical Research Center (KFMRC), King Abdulaziz University, Jeddah, Saudi Arabia.

\section{References}

Ajlan AM, Ghanem GAM, Abdulsalam KS (2007) Tomato yellow leaf curl virus in Saudi Arabia: identification, partial characterization and virus-vector relationship. Arab J Biotech. 10:179-192.

Akhtar S, Khan AJ, Singh AK, Briddon RW (2014) Identification of a disease complex involving a novel monopartite begomovirus with beta- and alpha satellites associated with okra leaf curl disease in Oman. Arch Virol. 159:1199-1205.

Al-Saleh MA, Al-Shahwan IM, Brown JK, Idris AM (2014) Molecular characterization of a naturally occurring interspecific recombinant begomovirus with close relatives widespread in Southern Arabia. Virol J. 11:103.

Briddon R, Bull SE, Mansoor S, Amin I, Markham PG (2002) Universal primers for the PCR-mediated amplification of DNA $b$, a molecule associated with some monopartite begomoviruses. Mol Biotech. 20:315-318.

Briddon RW, Bull SE, Amin I, Idris AM, Mansoor S, Bedford ID, Dhawan P, Rishi N, Siwatch SS, Abdel-Salam AM (2003) Diversity of DNA $\beta$ : a satellite molecule associated with some monopartite begomoviruses. Virol. 312: 106-121

Briddon RW, Bull S E, Amin I, MansoorS, Bedford ID, Rishi N, Siwatch SS, Zafar M Y, Abdel-Salam AM, Markham PG (2004) Diversity of DNA 1; a satellite-like molecule associated with monopartite begomovirus-DNA-b complexes. Virol. 324: 462-474.

Briddon RW, Brown JK, Moriones E, Stanley J, Zerbini M, Zhou X, Fauquet CM (2008) Recommendations for the classification and nomenclature of the DNA-b satellites of begomoviruses. Arch Virol. 153: 763-781.

Brown JK, Fauquet CM, Briddon RW, Zerbini M, Moriones E, Navas-Castillo J (2012) Family-Geminiviridae. In: King, AM, Lefkowitz, E, Adams MJ, Carstens EB (Eds.), Virus taxonomy: ninth report of the international committee on taxonomy of viruses. Elsevier, San Diego, 351-373.

Brown JK, Zerbini FM, Castillo JN, Moriones E, Sobrinho RR, Silva JCF, Olive EF, Briddon R. W, Zepeda CHN, Idris A, Malathi VG, Martin DP, Bustamante RR, Ueda S, Varsani A (2015) Revision of begomovirus taxonomy based on pair wise sequence comparisons. Arch Virol. 60: 1593-1619.

Cui X, Tao X, Xie Y, Fauquet CM, Zhou X (2004) A DNA b associated with tomato yellow leaf curl China virus is required for symptom induction. J Virol. 78: 13966-13974.

Duffy S, Holmes EC (2008) Phylogenetic evidence for rapid rates of molecular evolution in the single-stranded DNA begomovirus tomato yellow leaf curl virus. J Virol. 82:957965.

Fauquet CM, Briddon RW, Brown JK, Moriones E, Stanley J, Zerbini M, Zhou X (2008) Geminivirus strain demarcation and nomenclature. Arch Virol. 153:783-821.

Garcia-Andres S, Accotto GP, Navas-Castillo J, Moriones E (2007) Founder effect, plant host, and recombination shape the emergent population of begomoviruses that cause the tomato yellow leaf curl disease in the mediterranean basin. Virol. 359:302-312.

Ha C, Coombs S, Revill P, Harding R, Vu M, Dale J (2008) Molecular characterization of begomoviruses and DNA satellites from Vietnam: additional evidence that the new world geminiviruses were present in the old world prior to continental separation. J G Virol. 89: 312-326.

Hosseinzadeh MR, Bakhsh MS, Osaloo SK, Brown JK (2014) Phylogenetic relationships, recombination analysis, and genetic variability among diverse variants of tomato yellow leaf curl virus in Iran and the Arabian Peninsula: further support for a tomato yellow leaf curl virus center of diversity. Arch Virol. 159:485-497.

Idris AM, Brown JK (2005) Evidence for interspecificrecombination for three monopartite begomoviral genomes associated with the tomato leaf curl disease from central Sudan. Arch Virol. 150:1003-1012.

Idris AM, Shahid MS, Briddon RW, Khan AJ, Zhu JK, Brown JK (2011) An unusual alpha satellite associated with monopartite begomoviruses attenuates symptoms and reduces betasatellite accumulation. J G Virol. 92:706-717.

Idris AM, Abdullah NM, Brown JK (2012) Leaf curl diseases of two Solanaceous species in Southwest Arabia are caused by a monopartite begomovirus evolutionarily most closely related to a species from the Nile Basin and unique suite of betasatellites. Virus Res. 169:296-300.

Idris A, Al-Saleh M, Piatek MJ, Al-Shahwan I, Ali S, Brown JK (2014) Viral Metagenomics: analysis of begomoviruses by Illumina high-throughput sequencing. Viruses. 6:12191236.

Kenyon L, Tsai WS, Shih SL, Lee LM (2014) Emergence and diversity of begomoviruses infecting solanaceous crops in East and Southeast Asia. Virus Res. 186: 104-113.

Khan AJ, Idris AM, Al-Saady NA, Al-Mahruki MS, AlSubhi AM, Brown JK (2008) A divergent isolate of tomato yellow leaf curl virus from Oman with an associated DNA beta satellite: an evolutionary link between Asian and the Middle Eastern virus-satellite complexes. Virus Genes. 36:169-176.

Khan A J, Akhtar S, Al-Zaidia, Singh AK, Briddon RW (2013a) Genetic diversity and distribution of a distinct strain of chili leaf curl virus and associated betasatellite infecting tomato and pepper in Oman. Virus Res. 177: $87-$ 97.

Khan AJ, Akhtar S, Singh AK, Briddon RW (2013b) A distinct strain of tomato leaf curl Sudan virus causes tomato leaf curl disease in Oman. Plant Dis. 97:1396-1402.

Khan AJ, Mansoor S, Briddon RW (2014) Oman: a case for a sink of begomoviruses of geographically diverse origins. Trends Plant Sci. 19:67-70.

Lazarowitz SG (1992). Geminiviruses: Genome structure and gene function. Crit Rev Plant Sci. 11: 327-349.

Lefeuvre P, Martin DP, Harkins G, Lemey P, Gray AJA, Meredith S (2010) The spread of tomato yellow leaf curl virus from the Middle East to the World. PLoS Patho. 6: e1001164.

Muhire BM, Varsani A, Martin DP (2014) SDT: A virus classification tool based on pairwise sequence alignment and identity calculation. PLoS One.9:e108277.

Saunders K, Stanley J (1999) A nanovirus-like component associated with yellow vein disease of Ageratum conyzoides: evidence for interfamilial recombination between plant DNA viruses. Virol. 264:142-152.

Saunders K, Briddon RW, Stanley J (2008) Replication promiscuity of DNA-b satellites associated with monopartite begomoviruses; deletion mutagenesis of the ageratum yellow vein virus DNA-b satellite localizes 
sequences involved in replication. J G Virol. 89: 31653172.

Seal SE, vanden Bosch F, Jeger MJ (2006) Factors influencing begomovirus evolution and their increasing global significance: implications for sustainable control. Crit Rev Pla Sci. 25:23-46.

Sivalingam PN, Malathi VG, Varma A (2010) Molecular diversity of the DNA-beta satellites associated with tomato leaf curl disease in India. Arch Virol. 155:757-64.

Tamura K, Stecher G, Peterson D, Filipski A, Kumar S (2013) MEGA 6: Molecular evolutionary genetics analysis version 6.0. Mol Biol Evol. 30:2725-2729.

Varsani A, Navaz-Castillo J, Moriones E, Hernández-Zepeda C, Idris A, Brown JK, Zerbini FM, Martin DP (2014) Establishment of three new genera in the family Geminiviridae: Becurtovirus, Eragrovirus and Turncurtovirus. Arch Virol. 159: 2193-2203.
Yang X, Xie Y, Raja P, Li S, Wolf JN, Shen Q, Bisaro DM, Zhou X (2011) Suppression of methylation-mediated transcriptional gene silencing by $\beta \mathrm{C} 1-\mathrm{SAHH}$ protein interaction during geminivirus betasatellite infection. PLoS Patho. 7(10):e1002329.

Zhang Z, Chen H, Huang X, Xia R, Zhao Q, Lai J, Teng K, Li Y, Liang L, Du Q, Zhou X, Guo H, Xie Q (2011) BSCTV C2 attenuates the degradation of SAMDC1 to suppress DNA methylation-mediated gene silencing in Arabidopsis. Plant Cell. 23:273-288. 